Andriy Vindyk, Ph.D., prof. National University «Zaporizhzhia Polytechnic», Zaporizhzhia, Ukraine ORCID: 0000-0001-5495-4350

Ievgeniia Zakharina, Ph.D., prof. Classic Private University, Zaporizhzhia, Ukraine ORCID: 0000-0002-0222-3385

Tetiana Samolenko, $\mathrm{PhD}$ in Physical Training and Sport Kyiv National University of Trade and Economics, Kiev, Ukraine ORCID: 0000-0003-4102-6322

\title{
CURRENT STATE AND FEATURES OF DEVELOPMENT OF WINTER TYPES OF REST IN UKRAINE
}

The current state of winter holidays in Ukraine was considered. It is marked, that ski tourism industry in Ukraine is practically unfilled and not able to contain persons who interested in rest in mountains or on skis. It is indicated on the danger of tourists constrained with the use of old equipment. Poor quality of service for tourists, which does not meet international standards, is defined.

Keywords: winter type of tourism, resort, tourism, active rest.

Relevance of the research topic. The intensive development of tourism in the world has accelerated the development of mountainous areas and the improvement of winter types in tourism. Winter holidays are directly dependent on climatic conditions and the availability of snow and his volume. This type of tourism is quite active and sometimes requires serious sports training. Winter holidays allow you to take advantage of the many subspecies of winter tourism - skiing, snowboarding and snow tubing, ice skating and snowmobiling, as well as enjoy winter tourist areas swimming in thermal springs.

Formulation of the problem. In the modern world, winter tourism begins to grow into one of the most popular types of active rest. It isn't only prestigious, but also economically important for countries with winter tourism centers on their territory, since they receive a significant contribution to the income of their budgets in the form 
of taxes from tourism activities and industries serving the winter tourism industry. The more than half of all profits from winter types of tourism is created by skiing tourism.

Analysis of the last researches and publications. The main aspects of the study of this topic are covered in the scientific works of such domestic and foreign scientists as: Babkin A.V, Gorbunov V.S, Guk N.A, Remizov L.P and others. A winter holiday is a visit to a tourist area in the winter. It gives an opportunity to take advantage of a large number of subspecies of winter tourism - skiing, snowboarding, ice rinks, sledges and snowmobiles, as well as bathing in thermal springs in winter tourist areas [7].

Winter holidays depend on climatic conditions. Of paramount importance is the presence of a dense snow cover for four to five months of the year. The following important factors are: the height of the terrain, the features of the terrain, the weather conditions of the ski seasons, the nature of vegetation, the absence of avalanche and mudslides, as well as the diversity and uniqueness of landscapes.

The presence of dense snow cover depends not only on the height, but also on the location of the area, its proximity to the sea, the direction of mountain ranges, vegetation. The state of the snow cover is affected not only by the temperature, but also by the wind, which blows away the snow in convex areas and forms hard snow jams. To eliminate its negative impact, routes are laid on wooded slopes. They better preserve the snow cover and provide a more comfortable feeling when riding. However, in this case, additional costs are required for clearing the route of trees and for engineering and geological surveys to determine the stability of the slope after uprooting trees. Such conditions are often found at high altitudes in the mountains, and places of mass skiing on steep slopes, the snow becomes hard and icy from rolling it up by skiers [1].

The length of the ski season is great importance when operating the trails. It can be increased by selecting tracks on the slopes of the southern exposure for use primarily in winter and on the slopes of the Northern exposure, which are skated in the spring, when the snow cover of the southern slopes begins to melt. Modern resorts use snow guns to continue the skiing season. When choosing slopes for skiing, pay attention to the avalanche danger that arises not only from a large amount of snow precipitation and other weather conditions, but also from the steepness of the slopes and the nature of the vegetation. The largest number of avalanches is typical for nonvertical concave slopes with a range of steepness from 25 to 50 (table 1) [4].

Table 1

\section{Assessment of recreational resources of the territory for the development of winter tourism}

\begin{tabular}{|l|c|c|c|}
\hline & \multicolumn{3}{|c|}{ Recreational assessment } \\
\hline Height of the terrace, $\mathrm{m}$ & $1000-2500$ & $2500-3000$ & $3000-4000$ \\
\hline $\begin{array}{l}\text { Distance between the } \\
\text { highway and the hotel, } \mathrm{km}\end{array}$ & Less than 1 & $1-5$ & $5-30$ \\
\hline
\end{tabular}




\begin{tabular}{|l|c|c|c|}
\hline & \multicolumn{3}{|c|}{ Recreational assessment } \\
\hline Height of the terrace, $\mathrm{m}$ & $1000-2500$ & $2500-3000$ & $3000-4000$ \\
\hline Route length,m & More than 1000 & $200-1000$ & $50-200$ \\
\hline The average slope, degree & $12-18$ & $18-20 ; 10-12$ & $5-10 ; 20-25$ \\
\hline $\begin{array}{l}\text { The nature of the surface } \\
\text { slope }\end{array}$ & $\begin{array}{c}\text { Moderate with no stony } \\
\text { areas }\end{array}$ & $\begin{array}{c}\text { There are some stony } \\
\text { areas that are not } \\
\text { covered with snow }\end{array}$ & $\begin{array}{c}\text { Strongly } \\
\text { dissected with } \\
\text { many stone areas }\end{array}$ \\
\hline Avalanche danger & Avalanches are & $\begin{array}{c}\text { Avalanches are } \\
\text { possible }\end{array}$ & $\begin{array}{c}\text { There are } \\
\text { avalanche } \\
\text { dangerous areas }\end{array}$ \\
\hline
\end{tabular}

The study of natural and climatic conditions of the world's winter resorts showed that the most popular of them are located at an altitude of 1500-1800 m above sea level, the average temperature in January is 5-6, with long - term sunlight 19002000 hours per year, the amount of snow in development zone is up 3 meters. The above options correspond to resorts in Western Europe. The countries of this region are ahead of the world in terms of the number of winter resorts and the total length and equipment of trails.

Ski tourism is an extreme winter and combined type of tourism that includes elements of following types: recreational, amateur sports ecological tourism. It combines mountain tourism (snowboarding) and ski tourism (skiing) [2]. Most types of snowboarding do not require infrastructure other than skiing, and therefore snowboarding is available at all ski resorts.

Presentation of the main material. The purpose of the study is to study the state and prospects of development of winter recreation and develop a new excursion program for winter recreation in Bukovel. Ski tourism occupies a leading place in the world and Ukraine is no exception. Winter resorts in Ukraine are located in the Carpathian region. The Carpathians are the oldest mountain range in Europe, a distinctive cultural region. The Ukrainian Carpathians stretch from East to West and consist of five main regions (ridges): the Marmorosh Alps, Montenegro, the Svidovets ridge, the Gorgansky ridge, and the Borzhavsky ridge. The highest mountain range of the Ukrainian Carpathians is Montenegro (average height of $1800 \mathrm{~m}$ ) and mount Petros $(2020 \mathrm{~m})$ is located next to it. There are also winter resorts in Transacarpathian, Chernivtsi, IvanoFrankivsk and Lviv regions. In total, there are 51 ski resorts in Ukraine (table. 2) [6].

Table 2

\section{Winter resorts in Ukraine}

\begin{tabular}{|l|l|}
\hline \multicolumn{1}{|c|}{ Region } & \multicolumn{1}{|c|}{ The resort name } \\
\hline Trancscarpathian & $\begin{array}{l}\text { Bukovel, Slavske, Dragobrat, Izky, Pylypets, Bruise, Voevodino, Krasiya, } \\
\text { Rakov, Khust, Yasinya, Uzhok }\end{array}$ \\
\hline Ivano-Frankivsk & Verkhovyna, Yablunytsya, Vorokhta, Yaremche, Sheshory, Tudov \\
\hline Lviv & Play. Zakhar Berkut, Tysovets, Oryavchyk, Rozluch \\
\hline Chernivtsi & Migovo, Gorbovo, Sunny Valley, Lopushka, Nemich Pass \\
\hline
\end{tabular}


You can also take part in winter activities, namely sledding and skating rinks in the following areas: Dnipro region, (Lavina tourist complex), Poltava (Sorochin Yar, Skipens, Korchak), Kiev (Vyshgora and Protasov Yar) and Cherkasy (Vodyaniki). The most favorable area of Ukraine for active winter recreation is considered to be the ski resorts of the Carpathians. Sufficient snow and the quality of the lifts, the complexity and variety of descents, prices available to most vacationers, magnificent nature. The most famous and popular resorts in Ukraine in the Carpathian Mountains are Bukovel, Slavskoe, Dragobrat (table. 3) [5].

Table 3

\section{Technical characteristics of the slopes of the Carpathian region resorts}

\begin{tabular}{|l|c|c|c|c|}
\hline The resort name & $\begin{array}{c}\text { Height of the } \\
\text { resort, } \mathrm{m}\end{array}$ & $\begin{array}{c}\text { Total length of } \\
\text { trails, km }\end{array}$ & Number of lifts & $\begin{array}{c}\text { Capacity } \\
\text { Thousands } \\
\text { people/year }\end{array}$ \\
\hline Bucovel & 920 & 50 & $\begin{array}{c}17 \text { of them } \\
\text { chairlifts }-17 \\
\text { mugs }-1\end{array}$ & 33000 \\
\hline Dragobrat & 130 & 10 & $\begin{array}{c}14 \text { of them } \\
\text { chairlifts }-10 \\
\text { mugs-4 }\end{array}$ & 25015 \\
\hline Slavskoe & $857-1243$ & 43 & $\begin{array}{c}20 \text { of them } \\
\text { chairlifts }-2 \\
\text { mugs- } 8\end{array}$ & 29899 \\
\hline
\end{tabular}

The next largest number of ski resorts in Ukraine is Ivano-Frankivsk region. Ivano-Frankivsk region is located in depths of the highest mountain ranges of Ukraine. On the territory of the region there are such ski resorts as Yablunitsa, Vorokhta, Vyshkov, Kosov, Tudov, Shesohory, Yaremche [5].

The third district is located in the Lviv region, which ia located in the West of Ukraine, and is characterized by a variety of reliefs. There are such winter resorts as Plai (plavye village), Zakhar Berkut (Volosyanka village), Oryavhik, Rozluch and Tisovets. The fourth district of winter recreation Chernivtsi region. This is the smallest region in Ukraine, which, however, is home to several ski resorts: Migovo, Gorbovo, Lopushna, Nemchich, Pass, Tsetsino and Sunny Valley. The most popular resort in the region is Migovo.

In Ukraine, you can do winter recreation in the Dnipro region in the entertainment tourist complex «Lavina», it is located at the foot of the picturesque slope of the tunnel beam (street Space) the city of Dnipro. The only one of its kind on the Dnipro, the Park offers vacationers: a ski slope- $350 \mathrm{~m}$, a track for tubing descent and skating rink of 1800 square meters.

In Poltava region, the Sorochin Year ski complex is equipped with new lift, a range of rental products, as for small scale complex. On the territory of the complex there are the following tracks of the $300 \mathrm{~m}$ each; training track tubing track. And such 
lifts: 2 rope lifts of $260 \mathrm{~m} .1$ children lift of $180 \mathrm{~m}$ (hook «Dergunok»). They work from 10 to 20:00. Monday - from 14:00. Night skiing takes place at a fixed time from 18:00 to 21:00.In the compex you can engage in such time of winter recreation as: skiing, snowboarding, skating rinks, sledges, visit a specially prepared tyubingtrasu. The real winter is provided with snow cannons the tracks are prepared by ratraks [3].

In the Kyiv region in the comlex Vyshgora and Protasov Yar. Vyshgora is located in the centre of Kyiv, within a 15 minute drive from Kiev. It was founded in 2007 as a ski resort. Over 10 of operation, the complex has become, as well as snow tubing for riding on inflatable tubes. Equipment rental is available on site.

Conclusion. So, Ukraine has all the conditions for the development of winter recrecreation, but today the infrastructure of winter resorts can be described as insufficiently developed. Firstly, the ski tourism industry in Ukraine ia almost empty, and the national tourist market is physically unable to accommodate those who want relax in the mountains on skis or snowboard. During the peak season, long queues for lifts also do not have enough places in hotels, so $2 / 3$ of tourists-skiers live in private sector, which is bad for development of tourism in the country. The second big problem is danger o tourists. Almost all resorts use old equipment - lifts, which can lead to injuries. The poor quality of tourist service does not meet international standards. Service personnel at resorts are at least 5 times less than necessary by the standards of the modern hospitality industry. There is also a problem of transport accessibility transport routes do not meet international requirements. Winter resorts should offer a variety of outdoor activities: from skiing and cross -country skiing to Snowmobiling and sledding on dog sleds, and in Ukraine more attention is given to mountain skiing and snowboarding.

\section{REFERENCES}

1. Babkin A.V. Special types of tourism. Climate features in ski tourism: tutorial. Phoenix, 2008. 120 p.

2. Glushko A.A., Sazykin A.M Geography of tourism 2000. 27 p.

3. Guk N.A. Perspective directions of tourism development in the region of Ukrainian Carpathians. Drohobych state Ivan Franco Pedagogical University № 4. 2006. 3 p.

4. Serdyuk O.M., Zaitseva V.M., Ponomarenko V.I., Kuklina T.S. Analysis and assessment of the potential of tourist territories: educational manuals for higher educational institutions of Zaporizhzhia region: LLC «Lips» LTD, 2013. 142 p.

5. Ski tourism in the Ukrainian Carpathians. Tourist library - [Electronic resource] - access to the site: http://tourlib.net/statti_tourism/karpaty.htm. The link ia valid on 11/22/2017.

6. Vachevsky M.V., Svintsov O.M., Kuznetsov V.F development of the recreational sphere in ehe Carpathian region. Ukrainian balneological journal, 2001. p. 99-104.

7. Zorin I.V., Kvartalnov V.A. Encyclopedia of tourism-M., Finance and statistics, $2000.312 \mathrm{p}$. 